HOW EFFECTIVE HAVE

LOCALISED COMMUNITY

ACTIONS AND TARGETED

MESSAGING ABOUT

POLICY DECISIONS BEEN?

Australia \&

New Zealand

School Of

Government 


\section{HOW EFFECTIVE HAVE LOCALISED COMMUNITY ACTIONS AND TARGETED MESSAGING ABOUT POLICY DECISIONS BEEN?}

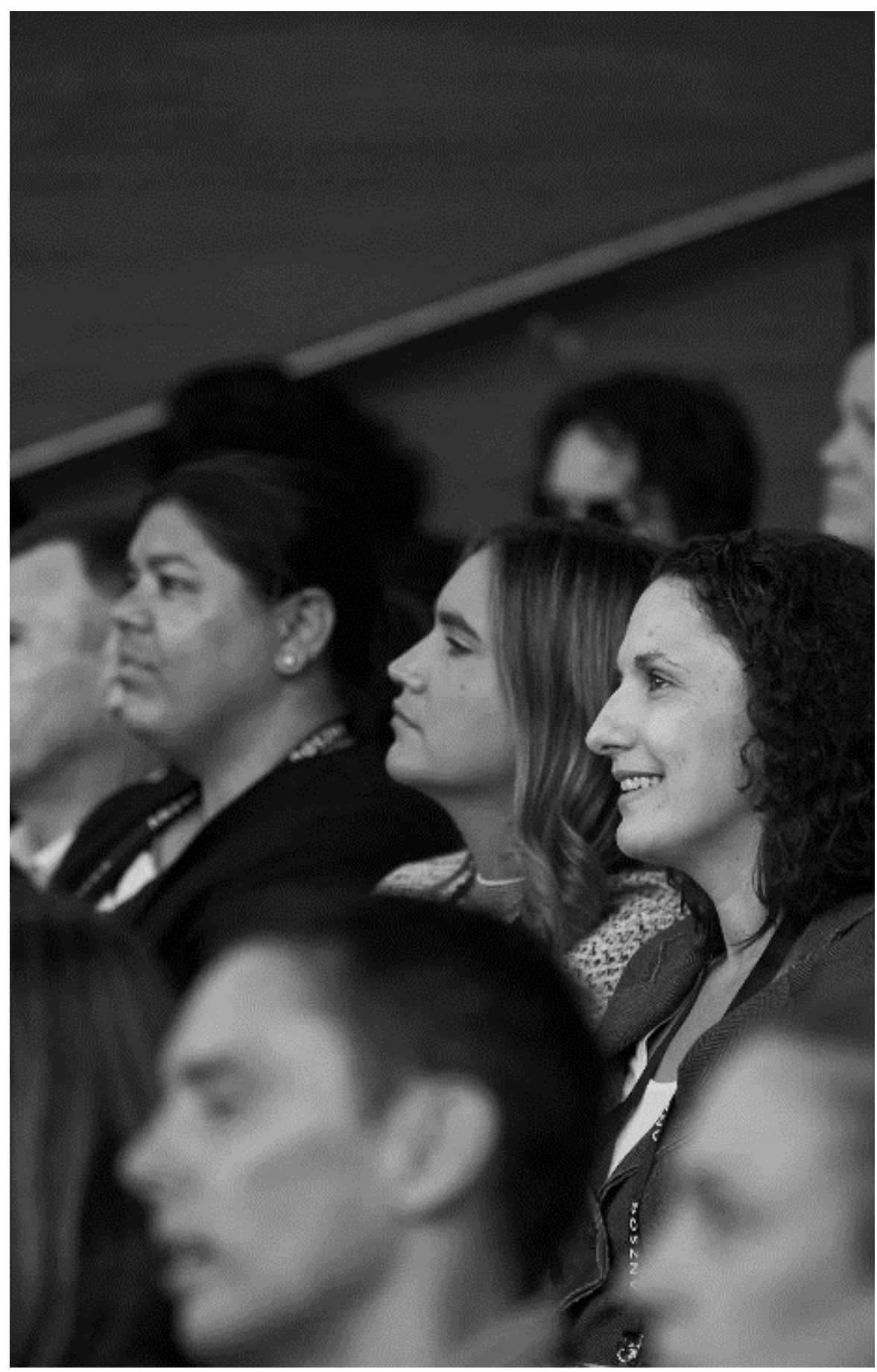

\section{Dr Barbara AllenVictoria University of Wellington - Te Herenga Waka}

\section{October 2020}

This paper was commissioned for ANZSOG and China's Central Party School's joint dialogue: Public administration reflections on the COVID19 response in China, Aotearoa-New Zealand and Australia.

This dialogue, supported by the Australian Department of Foreign Affairs and Trade, and the New Zealand Ministry of Foreign Affairs and Trade, was held in October 2020 to bring together expertise from the three countries and compare responses to COVID-19. ANZSOG and the Central Party School share an interest in providing quality training and education to build the capacities of the public officials of Australia, New Zealand and China. 


\section{CONTENTS}

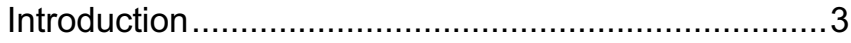

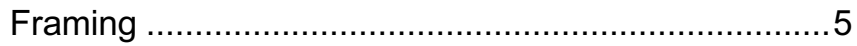

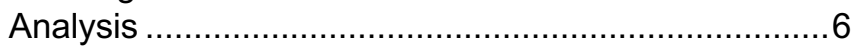

Public service and its publics: the Māori community ..8

Organisational capacity: Health system and PPE ......9

Public governance: Accountability \& rule of law ........10

Conclusion .......................................................... 12 


\section{Introduction}

New Zealand is no stranger to crises and disasters - in recent years we have had the Christchurch earthquake of 2011, the Kaikoura earthquake of 2016, the terrorist attack on the Muslim mosques in 2019 and the Whakaari/White Island eruption in 2019. The COVID-19 pandemic is revealing itself to be more impactful than anyone could have predicted.

There have been an overwhelming number of items in the mass media about the leadership of Prime Minister Jacinda Ardern (e.g. Friedman, 2020; Lux, 2020; Blackwell, 2020). The power of her personality is a significant factor in the way that New Zealand responded to the immediate emergency. As Heifetz et al. note $(2009$, p. 3) "empathy will be as essential for success as the strategic decisions [that are made]." While Ardern's leadership is undoubtedly critical to the success of New Zealand thus far, there are many more elements that deserve exploration. Thus, this is not a paper about leadership per se. Nor is it a paper about the economy. Here we endeavour to consider a small selection of policy decisions, system characteristics and the resulting actions and look at their effectiveness.

New Zealand is of course, a small Pacific nation of five million people spread out over two main islands and includes the 'realm' islands of the associated states of Niue, Cook Islands and Tokelau. While 70 per cent of the population claims European descent, New Zealand's indigenous Māori population of 16.5 per cent are partners in the Treaty of Waitangi that recognises Māori as 'tangata whenua' (people of the land) and holders of Te Reo Māori and Tikanga Māori (the language and culture of the people). Asians make up a further $15 \%$ and Pasifika peoples ${ }^{1}$ make up $8 \%$ of the population(Stats New Zealand, 2019). The diverse nature of the New Zealand population was a critical element of the response to COVID-19.

A very brief timeline outlining key dates and events associated with COVID-19 sets the stage.

\begin{tabular}{|l|l|l|}
\hline Date & Event & Comment \\
\hline 28 February & 1st case of COVID-19 in NZ & NZ resident returning from Iran \\
\hline 11 March & $\begin{array}{l}\text { PM initially bans travellers from } \\
\text { China }\end{array}$ & $\begin{array}{l}\text { NZ closely monitoring situation } \\
\text { in PRC, Korea, Italy and Iran }\end{array}$ \\
\hline WHO declares a pandemic & $\begin{array}{l}\text { By then five confirmed or } \\
\text { probable cases been reported in } \\
\text { NZ, first two arrived from Iran } \\
\text { and Italy where major outbreaks } \\
\text { taking off } \\
\text { Gatherings traced to overseas } \\
\text { contacts } \\
\text { Anyone arriving must self-isolate }\end{array}$ \\
\hline
\end{tabular}

1 The Ministry of Health identifies 18 Pacific ethnic profiles. The largest of these are Samoan, Cook Island Māori, Tongan, Fijian, Tokelauan, Tuvaluan. 


\begin{tabular}{|c|c|c|}
\hline By 19 March & $\begin{array}{l}\text { Banned mass gatherings over } \\
500 ; \text { Health package } \\
\text { announced; Wage subsidies } \\
\text { announced, business tax } \\
\text { changes } \\
\text { 'Unite against COVID-19' } \\
\text { advertisement campaign }\end{array}$ & $\begin{array}{l}\text { By now, border had been closed } \\
\text { to nearly everyone } \\
\text { Website covid19.govt.nz } \\
\text { became repository of all } \\
\text { information }\end{array}$ \\
\hline 21 March & $\begin{array}{l}\text { PM announced four-level alert } \\
\text { system }\end{array}$ & NZ enters level 2, 52 cases \\
\hline 23 March & $\begin{array}{l}\text { Epidemic Notice announced for } \\
\text { three month period, NZ enters } \\
\text { Level Three }\end{array}$ & $\begin{array}{l}\text { Allows extensions of temporary } \\
\text { visas }\end{array}$ \\
\hline 25 March & $\begin{array}{l}\text { State of national emergency, NZ } \\
\text { enters Level Four, lockdown at } \\
\text { midnight - } \\
\text { Parliament suspended, } \\
\text { COVID-19 Response (urgent } \\
\text { management measures) } \\
\text { Legislation Act } \\
\text { Existing legislation becomes } \\
\text { relevant - Health Act } 1956 \text { etc }\end{array}$ & $\begin{array}{l}\text { Only essential services } \\
\text { permitted to operate, social } \\
\text { gatherings prohibited, social } \\
\text { distancing of two metres, } \\
\text { schools closed } \\
\text { NZ was rated among the most } \\
\text { stringent in the world at that time }\end{array}$ \\
\hline 2 April & $\begin{array}{l}\text { Reported cases per day peaked } \\
\text { at } 89\end{array}$ & $\begin{array}{l}\text { Pressure on PM to loosen } \\
\text { restrictions over Easter, she } \\
\text { does not relent }\end{array}$ \\
\hline 28 April & $\begin{array}{l}\text { New Zealand goes to Level } \\
\text { Three }\end{array}$ & Some businesses able to open \\
\hline 14 May & New Zealand goes to Level Two & Testing hits 8000 per day \\
\hline 8 June & $\begin{array}{l}\text { New Zealand moves to Level } \\
\text { One }\end{array}$ & Economy begins resuming \\
\hline & smission & \\
\hline
\end{tabular}




\begin{tabular}{|l|l|l|}
\hline 11 August & $\begin{array}{l}\text { New cases, community } \\
\text { transmission emerge in } \\
\text { Auckland }\end{array}$ & $\begin{array}{l}\text { Transmission contained in } \\
\text { clusters }\end{array}$ \\
\hline
\end{tabular}

Table based on information from various sources including (Duncan, 2020)

The story of the COVID-19 New Zealand response cannot be fully covered here. I draw your attention to Policy Quarterly (16)(3) August 2020, and to a case study 'Global Challenges of Covid-19 - New Zealand Beats Back COVID-19' (Cameron, 2020).

\section{Framing}

The framing for this analysis draws on the Prevention - Preparedness - Response - Recovery (PPRR) (Cronstedt, 2002; Edrissi et al., 2013; Khan et al., 2008) risk management model and a set of themes from recent public administration literature.

Using Khan et al. (2008) we identify key stages: before a disaster (pre-disaster including prevention and preparedness); during a disaster (disaster occurrence including response) and after a disaster (post-disaster and recovery). There is an underlying objective of enhancing community resilience to all types of major catastrophes (Himes-Cornell et al., 2018).

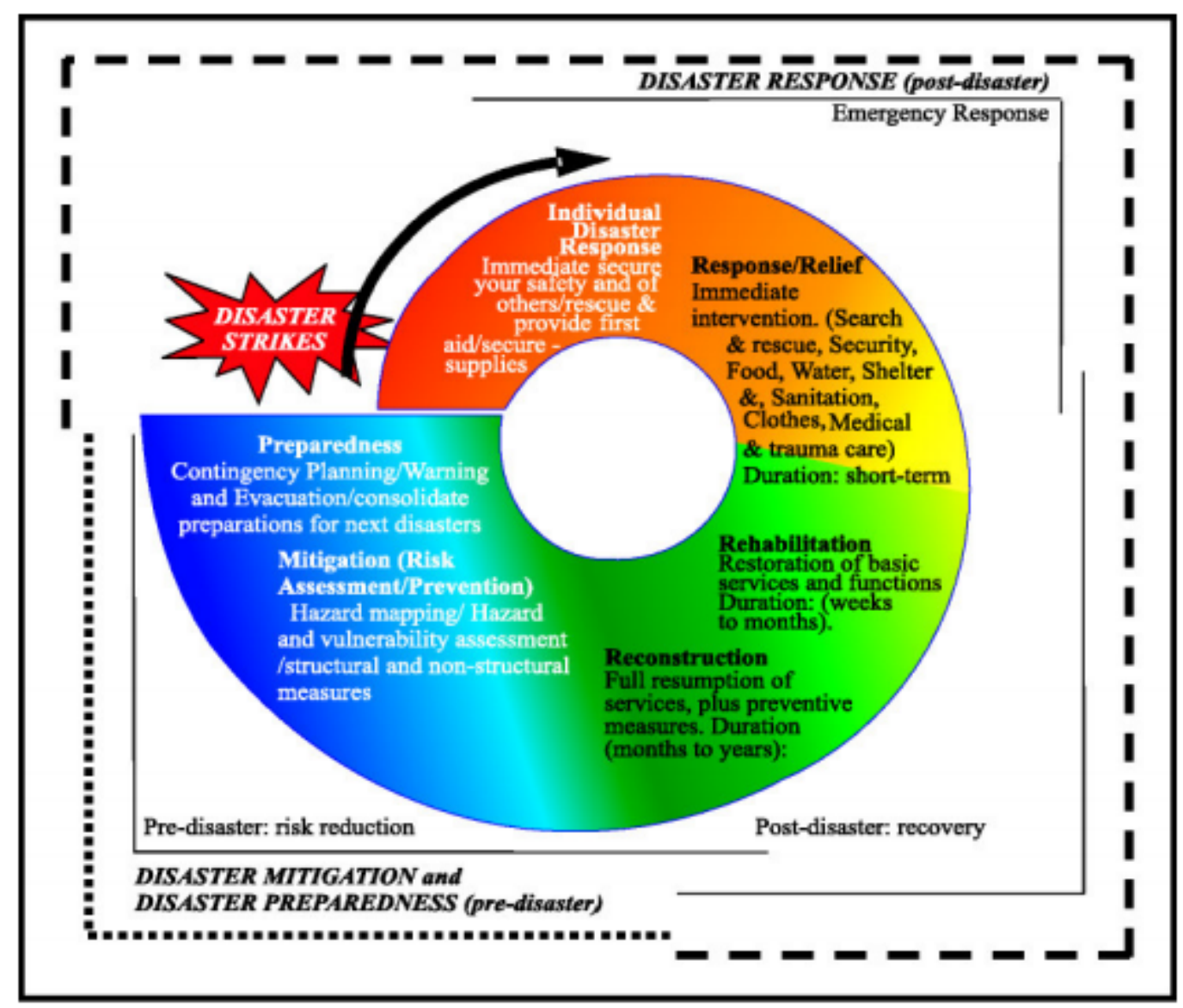

(Khan et al., 2008, p. 47) Disaster Management 
Academics across the range of public administration literature are exploring the impact of the COVID-19 pandemic on institutions, management and governance (Capano et al., 2020; Dunlop et al., 2020; Henrickson, 2020; O'Flynn, 2020).

Dunlop and co-authors sketch out a series of themes that they consider to be important for the field of public policy and administration and central to the challenges presented by COVID-19 (Dunlop et al., 2020). I have designed a heuristic that captures four of those themes, set against the PPRR elements in order to explore effectiveness.

\section{Effectiveness}

\begin{tabular}{l|l}
$\begin{array}{l}\text { Frame } \\
\text { (Dunlop et al., } \\
\text { 2020) }\end{array}$ & Action \\
$\begin{array}{l}\text { Policy decision } \\
\text { and design }\end{array}$ & $\begin{array}{l}\text { Alert Levels \& } \\
\text { Lockdown }\end{array}$ \\
\hline $\begin{array}{l}\text { Public service } \\
\text { and its publics }\end{array}$ & $\begin{array}{l}\text { The Māori } \\
\text { Community }\end{array}$ \\
\hline $\begin{array}{l}\text { Organisational } \\
\text { capacity }\end{array}$ & $\begin{array}{l}\text { Health system } \\
\text { \& PPE }\end{array}$ \\
\hline $\begin{array}{l}\text { Public } \\
\text { governance }\end{array}$ & $\begin{array}{l}\text { Accountability } \\
\text { and rule of law }\end{array}$ \\
\hline
\end{tabular}

We use this heuristic in the conclusion based on the Analysis of each theme and action

\section{Analysis}

\section{Policy decision and instrument design: Alert Levels \& Lockdown}

One of the most influential decisions taken related to the emergency and disaster unfolding, was the design and implementation of the 'Alert Levels'. On 21 March 2020 the PM announced the National Four Stage Alert System designed to manage and minimise the risk of COVID-19.

Ardern approved a plan to close the border to foreigners on March 18. It was becoming clear that public health was unable to implement widespread testing nor was it able to effectively trace the contacts of those infected. This was going to be a whole-of-government response but it would be in the communities where the key actions would take place. Ardern told the response team that she wanted an alert-level system like the six-level system that GeoNet, the governments geological hazard monitoring system used for volcanic eruptions (Cameron, 2020, p. 12). Singapore's DORSCOM system was shown to Ardern by New Zealand's Chief Science Officer Gerrard, and she was extremely enthusiastic about using it as a communication tool (Winkless, 2020). 


\section{Elimination Strategy}

\section{Alert Level}

Level 4 - Lockdown -

Likely the disease is not contained

Level 3 - Restrict

High risk the disease is not contained

Level 2 - Reduce

The disease is contained but the risk of community transmission remains

Level 1 - Prepare

The disease is contained in New Zealand

\section{Risk Assessment}

Sustained and intensive community transmission is occurring

Multiple cases of community transmission occurring, multiple active clusters in multiple regions

Limited community transmission could be occurring, active clusters in more than one region

Covid-19 is uncontrolled overseas, sporadic imported cases, isolated local transmission could be occurring in New Zealand

New Zealand COVID-19 Alert Levels Summary (partial table) ${ }^{2}$

\section{Prevention}

The Alert Level system was more than a policy - it formed a vulnerability assessment, a strategy, an implementation approach and behavioural rules based on high trust and voluntary compliance, all rolled into one piece of communication. However, at the time of design, it contained elements of a prevention strategy for an event that had already occurred.

\section{Preparedness}

The effectiveness of the Alert Levels could not make up for the fact that New Zealand had been given a poor assessment of its pandemic preparedness in 2019, receiving a score of only 54/100 on the Global Health Security Index and had a poorly developed epidemiology workforce and an underfunded public health system. It was also criticised as having done negligible work on refining the border control aspects of its pandemic plan (Wilson et al., 2020). The existing influenza pandemic plan was the main guidance available.

\section{Response}

With relatively high trust in scientific experts and officials, and masterful communication of the Alert levels, there was extensive public support for the control measures as reflected in surveys and media discourse (Wilson et al., 2020, p. 21).

While there were very few violations in the initial lockdown, and very little resistance to the use of wide-ranging powers, it did appear that the official messaging went much further than the legal orders appeared to allow. In contrast to vociferous medical experts and scientific commentary, the legal experts were noticeably quiet (McLean, 2020) during initial lockdown.

\section{Recovery}

The Alert level approach itself has proven to be effective as a targeted set of ideas, a relatively easy-tocommunicate set of behaviours, constituting a frame of action for a society during a period of stress.

\footnotetext{
${ }^{2}$ www.covid19.govt.nz/assets/resources/tables/COVID-19-alert-levels-summary.pdf
} 
The Levels continue to be an effective lever as the pandemic evolves. New Zealand had a small further outbreak in Auckland in August necessitating the re-engagement of Level Three with significant restrictions. For businesses, anything beyond Level Two has become very problematic due to restrictions on numbers, enhanced public health requirements and a general slowing of activity.

\section{Public service and its publics: the Māori community}

In New Zealand the Treaty of Waitangi provides a framework for how the government and the indigenous community work together, with due respect for and consideration to Māori worldviews.

There was deep concern that there were no Māori representatives, Pacific community representatives, officials, or stakeholders at the key decision-making points during the early parts of the crisis (Hurihanganui, 2020). The government responded that they had always been communicating to Indigenous leaders at the appropriate levels, but this has remained a contentious issue.

\section{Prevention}

There was little mitigation in terms of planning for what impacts there might be upon the Māori population. The threat to the Māori population was significant given historical risk factors involving diabetes, cardiovascular disease, chronic respiratory illness and cancer (McMeeking and Savage, 2020). In the early phase, Maori had low rates of COVID-19 infection, approximately 8 per cent of confirmed cases, below the 16.5 per cent they make up of the national population (McMeeking p.37 - Ministry of Health 2020) Later on, further clusters impacted Māori communities bringing the statistics closer to the expected proportion of infection per head of population.

What protected the local communities is both their strength and their weakness. Close ties, existing networks, local communication, tikanga (Māori way of doing things), and respect for community elders - all helped to prevent a complete disaster in the early stages of COVID-19.

\section{Preparedness}

Many Māori either cannot access, or will not access, mainstream services, because of practical barriers such as inadequate transport, experiential barriers such as encountering systemic bias or perceptual barriers (that the service does not 'fit') (McMeeking and Savage, 2020). Over the years increasing kinds of services have been designed to try to respond to the problem of 'lack of fit' such as Whanau Ora - a large commissioning agency, and iwi-focused groups working in partnership with various Ministries. While the multitude of networks in existence were not purposefully directed at disaster planning, many of these proved essential in connecting to Māori communities during the initial period. Significant insight was gained by gathering information on the ground to find out the needs of families.

\section{Response}

The adaptability of the Māori community was demonstrated early on with cultural adaptation such as changing traditional greetings to non-touch. Māori networks reached those who may have been unreachable by other parties and a pre-existing level of trust enabled higher quality engagement and effective outcomes such as the distribution of food and practical resources, grants for home heating, and technology devices (McMeeking and Savage, 2020, p. 38).

A very interesting situation emerged in the regions of North Island, Taranaki, the East Coast and Northland, whereby iwis ${ }^{3}$ established their own checkpoints, stopping cars to query whether the occupants were complying with Level Three restrictions on inter-regional travel. Supported by local police, iwi volunteers would question car

\footnotetext{
${ }^{3}$ An iwi is the largest social unit of Māori society, may be known elsewhere as 'tribe'.
} 
occupants and turn them around if they were in violation of the restrictions. Strong opposition ensued (including political opposition), with some residents saying the checkpoints were unlawful. However, the Commissioner of Police said there was nothing unlawful about police-supervised roadblocks (Wade, 2020) and were aligned with government policy and enhancing community safety.

\section{Recovery}

In terms of localised community action, the iwi checkpoints are more than what they initially appear to be. At the time they could be characterised as a practical response to heightened vulnerability of the Mãori community(McMeeking and Savage, 2020) however it is argued that the checkpoints "reflected a broad, tacit expectation among many Māori communities that the government either would not or could not provide adequate protection for the distinctive realities within Māori communities and therefore it was necessary to take a [Do-itYourself] DIY approach."(McMeeking and Savage, 2020, p. 39)

The question will be whether the Māori and Pasifika responses, heavily focused on the community, are taken seriously as learning for the future.

\section{Organisational capacity: Health system and PPE}

New Zealand's lockdown measures and the border control measures along with the voluntary compliance of citizens to the rules mitigated against large numbers of hospital admittances and high mortality rates. However, issues emerged with respect to the organisational capacity of the system and none more stark than the problems that emerged with Personal Protective Equipment (PPE). Early on in the emergency, it became apparent that there was little information about the amount of PPE available, where the PPE was, whether it was in-date, how fast more could be obtained and how much it would all cost. At a local level, not having PPE or being uncertain about what, when and where it should be used became a source of huge frustration.

New Zealand has a semi-devolved health and disability system, with distributed responsibilities and complex arrangements between the Ministry of Health, District Health Boards, and other organisations. The Ministry of Health is responsible for monitoring and forecasting usage of the national reserve of PPE, and prioritising and allocating supplies when needed (Auditor-General, 2020) The situation with PPE was of such importance that the Auditor General decided to take an independent look at how the Ministry had been managing the national reserve and how the supply system worked.

\section{Prevention}

In early February 2020, the Ministry of Health did not know what PPE stock the District Health Boards held in their reserve supplies or have a system to forecast demand. "The devolved system of managing and distributing PPE stock for operational use was not able to manage the increased flow of stock needed during the COVID-19 response, and DHBs identified that some of the national reserve stock DHBs held had expired."(Auditor-General, 2020, p. 5)

On the positive side, there was some local supply - the Ministry had contracted a company in 2006 called QSi to domestically produce N95 and general purpose surgical masks to offset risks with sourcing internationally.

\section{Preparedness}

PPE was a critical local problem when COVID-19 hit, but the system itself was not well prepared. The Ministry of Health Influenza Pandemic Action Plan was in place since 2002 but it did not fully foresee the eventuality of an "aggressive, highly transmissible novel coronavirus for which there was neither antiviral medication nor

\footnotetext{
${ }^{4}$ PPE - personal protective equipment
} 
vaccine."(Duncan, 2020, p. 5) Between 2005 and 2010 the Public Health and Māori directorates were dismantled and there was a loss of public health analytical capacity" (Crampton et al., 2020, p. 32).

\section{Response}

At the front line, health and disability workers, and those they were caring for, felt that they needed a higher level of PPE to feel safe.

On 27 March 2020, the Ministry published guidance for District Health Boards on prioritising the use of PPE in particular clinical settings. Then it provided specific guidance for community care providers but, there were mixed messages about the use of PPE. Distribution by the District Health Boards was in response to what people were asking for rather than what the guidelines recommended. The community-based health and disability care providers said that the guidelines did not furnish what they felt they needed to feel safe delivering care. Providers also said that, even when they met the criteria, they experienced difficulties accessing PPE through the District Health Boards(Auditor-General, 2020, p. 18)

Guidelines were changed throughout April and May and there were multiple networks of communication to the local levels (Auditor-General, 2020, p. 19) Throughout this period, obtaining PPE turned into a severe local need and the New Zealand company Zuru, better known as a toymaker, quickly moved into the business of producing and delivering PPE (Newshub, 2020).

\section{Recovery}

With regards to PPE we cannot be caught short in terms of accessible supply and effectively supply chains. The Auditor-General (Auditor-General, 2020, p. 6) remarked, "To be sufficiently prepared in the future, the health and disability sector needs a clear understanding of what PPE is held where, who it should be provided to, a way of forecasting demand, and a scalable system for procuring and distributing stock...." The Ministry of Health responded to the Auditor-General's review and accepted all ten of the recommendations, with many of them moving forward this year (Dr Ashley Bloomfield, Director-General of Health, 2020)

With regards to the health system itself, building on the intensive work during the Covid-19 outbreaks (such as the Updated Covd-19 Māori Health Response Plan), there is undoubtedly substantial work to be done. As Crampton notes (2020, p. 34) "the extraordinary challenge that the COVID-19 experience delivered to the New Zealand health system has reinforced the value of a critical mass of public health institutional capacity and capability at the centre of our health system to exercise public health leadership and stewardship."

\section{Public governance: Accountability \& rule of law}

The nature of public governance in New Zealand had a significant impact on the success of the measures in response to COVID-19. The interactions between existing law, the powers conferred by those laws, the capacity to quickly create new 'institutions' able to oversee accountability - resulted in a fast-moving context of testing legitimacy at every stage and the demonstration of a system that was able to respond in real-time.

\section{Prevention}

The Government took a 'precautionary approach' in terms of public governance. In fact, the Civil Defence Emergency Act 2002 requires the New Zealand government to take a precautionary approach in the face of scientific uncertainty. "This meant that the government was required to weigh the ordinary risks to life and wellbeing against the risk of catastrophic collective harm in the form of huge numbers of deaths all at once and an existential threat to the population at large." (McLean, 2020, p. 12) The government was guided by their overall belief that health would be protected no matter the effect on the economic system and indeed that 'there's no wealth without health.' 


\section{Preparedness}

New Zealand was well prepared for this approach in terms of public governance - providing ways in which to enact an evidence-based, strict lockdown procedure within the law.

The Health Act of 1956 was key here, granting numerous powers to medical officers of health and the police during an epidemic, including the isolation of 'persons'. However, the Level Four lockdown put the entire population into isolation, this raised questions raised about lawfulness. Also there was confusion over lockdown rules regarding essential services and routine exercise.

\section{Response}

With Parliament suspended an Epidemic Response Committee was established on 25 March 2to consider and report to the House and wider government regarding the Government response to the outbreak. It had cross-party representation, was chaired by the Leader of the Opposition, and most of the deliberations and presentations were live-streamed over the internet.

With the resumption of Parliament on 28 April, it quickly passed the new COVID-19 Public Health Response Act 2020 , which was carefully tailored to the present emergency, putting powers the government had been exercising under various Acts in one omnibus bill. Crucially the powers were now in legislation, providing the possibility of parliamentary or public oversight, rather than in orders made by the Director-General of Health.

At the local level, enhanced collaboration seemed to characterise public governance during this period. In a centralised country such as New Zealand, where local governments have limited resources, and yet are critical to the everyday well-being of citizens, the way in which the response to COVID-19 happened showed their coordination capacity when under pressure.

The establishment of the COVID-19 Local Government Response Unit made up of central government, local government and peak body organizations, was a good example of the collaborative capacity between central and local government. The Unit managed the day-to-day engagement with councils; it was critical to translate the rules and regulations characterising each of the lockdown levels into specific operational guidelines for councils. Fifty legislative obstacles were identified and dealt with through the omnibus bill COVID-19 Response (Further Management Measures) Legislation Bill. This allowed for adjustment of by-election dates, and shortened consultation timeframes among other changes(Reid, 2020, p. 44).

\section{Recovery}

The Crown faced legal action over the lockdown laws in a number of areas. Notably, there was a question over whether the Director-General of Health could legitimately isolate or quarantine the entire nation under Section 70 of the Health Act. For the most part the judicial review considered that the Government had acted lawfully under the network of rules and laws covering their actions at the time. The process was an important one indicating that the government under the public governance system must be certain of where and how its powers derive, and that accountability is required at each stage of the process of dealing with an emergency situation.

In terms of recovery, while the COVID-19 initial period demonstrated the capacity for collaboration between central and local government as well as partnership between councils, in normal times councils compete with one another for resources; central government is usually the 'broker' making trade-offs rather than a constructive partner (Reid, 2020). Local communities are very diverse and the recovery will be political. 


\section{Conclusion}

We began by asking 'How effective have localised community actions and targeted messaging about policy decisions been?' Using our framework, how do the issues explored under the PA themes fare against the PPRR framework in the New Zealand context?

\section{Effectiveness}

\begin{tabular}{|c|c|c|c|c|c|}
\hline $\begin{array}{l}\text { Frame } 1 \\
\text { (Dunlop et al., } \\
\text { 2020) }\end{array}$ & Action & Prevention & Preparedness & Response & Recov \\
\hline $\begin{array}{l}\text { Policy decision } \\
\text { and design }\end{array}$ & $\begin{array}{l}\text { Alert Levels } \\
\text { and Lockdown }\end{array}$ & $\mathscr{V}$ & $\mathscr{V}$ & $\mathscr{N} \mathbb{N}$ & $\mathscr{N}$ \\
\hline $\begin{array}{l}\text { Public service } \\
\text { and its publics }\end{array}$ & $\begin{array}{l}\text { The Māori } \\
\text { Community }\end{array}$ & $\mathscr{V}$ & $\mathscr{N}$ & $\mathscr{N}$ & $\mathscr{q} ?$ \\
\hline $\begin{array}{l}\text { Organisational } \\
\text { capacity }\end{array}$ & $\begin{array}{l}\text { Health system } \\
\text { and PPE }\end{array}$ & $\mathscr{V}$ & $\mathscr{q}$ & $\mathscr{N}$ & $\mathscr{V} ?$ \\
\hline $\begin{array}{l}\text { Public } \\
\text { governance }\end{array}$ & $\begin{array}{l}\text { Accountability } \\
\text { and rule of law }\end{array}$ & $\mathscr{N} \mathscr{N}$ & $\mathscr{N}$ & $\mathscr{V} \mathbb{V}$ & $\mathscr{q} ?$ \\
\hline
\end{tabular}

\{3 marks indicates very good, 2 marks indicates satisfactory, 1 mark indicates weakness $\}$

First, the Alert Levels approach overall seems to be an effective action that was fairly quick to design due to preparedness for other crises and in its relative simplicity, easy to communicate. However, seen in combination with the preventive elements and organisational capacity of the health system, it could not on its own make up for weaknesses in preparedness.

Second, the Māori community has enormous internal capacity for communication and service support in times of stress, but the institutional arrangements may not have involved Māori decision-makers at the right levels, at the right times. Māori self-responsibility aided the overall New Zealand response in terms of the early phases of the pandemic and some strides have been made because of the pressure put on the Ministry of Health's Māori response action plan and the efforts to support Māori organisations going forward. If lessons are learned in terms of the positives that resulted from self-organisation and collaboration across service delivery areas and sectors, then New Zealand may be able to embed more preventive measures for the future.

The health system has only been explored briefly here, but we can judge that in terms of organisational capacity and strength in public administration, there is much to be learned and many actions to take to prepare for the next disaster. The health system was only able to respond in the way that it did, because of the Alert levels, the lockdown, the border controls, the capacity of the Māori community and the strength of wider public governance measures. Public health systems, PPE supply systems, and the organisation of the District Health Board system all require review and work with regards to prevention, preparedness, and response.

Finally, public governance in New Zealand is strong - where cracks appeared during the initial crisis (question over whether the government had gone 'too far'), debate, consultation, and even judicial review ensued within a legal system that upholds justice and considers that the trust of citizens in the government is a critical element of responding to emergencies. 
Despite relative worldwide success in response to the pandemic, New Zealand can be and must be better prepared for such deep and wide emergencies. Always, we must aim at reducing deaths, with less cost to economic activity and social connection. We have tested our systems in an extreme situation and found some wanting - but analysis points to where our efforts need to go. 


\section{References}

Auditor-General, C.A. (2020), Ministry of Health: Management of Personal Protective Equipment in Response to Covid-19, available at: https://oag.parliament.nz/2020/ppe/docs/ppe.pdf.

Blackwell, G. (2020), “Jacinda Ardern: 'Political leaders can be both empathetic and strong'”, The Guardian, 30 May, available at: http://www.theguardian.com/world/2020/may/31/jacinda-ardern-political-leaders-can-be-bothempathetic-and-strong (accessed 4 October 2020).

Cameron, B. (2020), "Captaining a Team of 5 Million: New Zealand Beats Back COVID-19, March - June 2020", Captaining a Team of 5 Million: New Zealand Beats Back COVID-19, March - June 2020, available at: https://successfulsocieties.princeton.edu/sites/successfulsocieties/files/NewZealand_COVID_FInal.pdf (accessed 1 October 2020).

Capano, G., Howlett, M., Jarvis, D.S.L., Ramesh, M. and Goyal, N. (2020), "Mobilizing policy (in) capacity to fight COVID-19: Understanding variations in state responses", Policy and Society, Taylor \& Francis, Vol. 39 No. 3, pp. 285-308.

Crampton, P., Matheson, D. and Cotter, M. (2020), "Assessing the Design and Capability of Our Public Health System in a Covid and Post-Covid New Zealand", Policy Quarterly, Vol. 16 No. 3, available at: https://ojs.victoria.ac.nz/pq/article/view/6552.

Cronstedt, M. (2002), "Prevention, preparedness, response, recovery-an outdated concept?", Australian Journal of Emergency Management, The, Emergency Management Australia, Vol. 17 No. 2, p. 10.

Dr Ashley Bloomfield, Director-General of Health. (2020), Response to Report - Ministry of Health: Management of Personal Protective Equipment in Response to COVID-19, Ministry of Health, available at: https://www.health.govt.nz/system/files/documents/pages/response_to_auditor-general__signed_letter_22.07.20.pdf.

Duncan, G. (2020), “The Covid-19 pandemic”, Policy Quarterly, Vol. 16 No. 3, available at:https://doi.org/10.26686/pq.v16i3.6546.

Dunlop, C.A., Ongaro, E. and Baker, K. (2020), "Researching COVID-19: A research agenda for public policy and administration scholars", Public Policy and Administration, SAGE Publications Ltd, Vol. 35 No. 4, pp. 365-383.

Edrissi, A., Poorzahedy, H., Nassiri, H. and Nourinejad, M. (2013), "A multi-agent optimization formulation of earthquake disaster prevention and management", European Journal of Operational Research, Elsevier, Vol. 229 No. 1 , pp. 261-275.

Friedman, U. (2020), “New Zealand's Prime Minister May Be the Most Effective Leader on the Planet", The Atlantic, 19 April, available at: https://www.theatlantic.com/politics/archive/2020/04/jacinda-ardern-new-zealandleadership-coronavirus/610237/ (accessed 4 October 2020).

Heifetz, R., Grashow, A. and Linsky, M. (2009), "Leadership in a (permanent) crisis", Harvard Business Review, Vol. 87 No. 7-8, pp. 62-9, 153.

Henrickson, M. (2020), "Kiwis and COVID-19: The Aotearoa New Zealand Response to the Global Pandemic", The International Journal of Community and Social Development, SAGE Publications India, Vol. 2 No. 2, pp. 121-133.

Himes-Cornell, A., Ormond, C., Hoelting, K., Ban, N.C., Zachary Koehn, J., Allison, E.H., Larson, E.C., et al. (2018), "Factors Affecting Disaster Preparedness, Response, and Recovery Using the Community Capitals Framework", Coastal Management, Taylor \& Francis, Vol. 46 No. 5, pp. 335-358. 
Hurihanganui, T. (2020), "Māori health professionals left out of Epidemic Response Committee meetings", RNZ, 4 May, available at: https://www.rnz.co.nz/news/te-manu-korihi/415747/maori-health-professionals-left-out-ofepidemic-response-committee-meetings (accessed 2 October 2020).

Khan, H., Vasilescu, L.G., Khan, A. and Others. (2008), "Disaster management cycle-a theoretical approach", Journal of Management and Marketing, ceeol.com, Vol. 6 No. 1, pp. 43-50.

Lux, A.A. (2020), "Open, honest and effective: what makes Jacinda Ardern an authentic leader", The Conversation, 26 May, available at: http://theconversation.com/open-honest-and-effective-what-makes-jacinda-ardern-anauthentic-leader-132513 (accessed 4 October 2020).

McLean, J. (2020), "Risk and the Rule of law", Policy Quarterly, Vol. 16 No. 3, available at: https://doi.org/10.26686/pq.v16i3.6548.

McMeeking, S. and Savage, C. (2020), "Maori Responses to Covid-19", Policy Quarterly, Vol. 16 No. 3, available at: https://ojs.victoria.ac.nz/pq/article/view/6553.

Newshub. (2020), "Kiwi company delivers millions of PPE supplies amid COVID pandemic", 21 September, available at: https://www.newshub.co.nz/home/new-zealand/2020/09/kiwi-company-delivers-millions-of-ppesupplies-amid-covid-pandemic.html (accessed 1 October 2020).

O'Flynn, J. (2020), "Confronting the big challenges of our time: making a difference during and after COVID-19", Public Management Review, Routledge, pp. 1-20.

Reid, M. (2020), “Collaboration in a Time of Covid-19", Policy Quarterly, Vol. 16 No. 3, available at: https://ojs.victoria.ac.nz/pq/article/view/6554.

Stats New Zealand. (2019), "New Zealand's population reflects growing diversity”, available at:

https://www.stats.govt.nz/news/new-zealands-population-reflects-growing-diversity (accessed 7 October 2020).

Wade, A. (2020), "Covid 19 Coronavirus: Police Commissioner Andrew Coster under fire for condoning community checkpoints", The New Zealand Herald, NZ Herald, 1 May, available at:

https://www.nzherald.co.nz/nz/news/article.cfm?c_id=1\&objectid=12328718 (accessed 4 October 2020).

Wilson, N., Boyd, M., Kvalsvig, A., Chambers, T. and Baker, M. (2020), "Public Health Aspects of the Covid-19 Response and Opportunities for the Post-Pandemic Era", Policy Quarterly, Vol. 16 No. 3, available at:https://doi.org/10.26686/pq.v16i3.6550.

Winkless, L. (2020), "COVID-19 Q \& A With New Zealand's Chief Science Advisor", Forbes Magazine, available at: https://www.forbes.com/sites/lauriewinkless/2020/04/01/covid-19-q--a-with-nzs-chief-science-advisor/ (accessed 1 October 2020). 


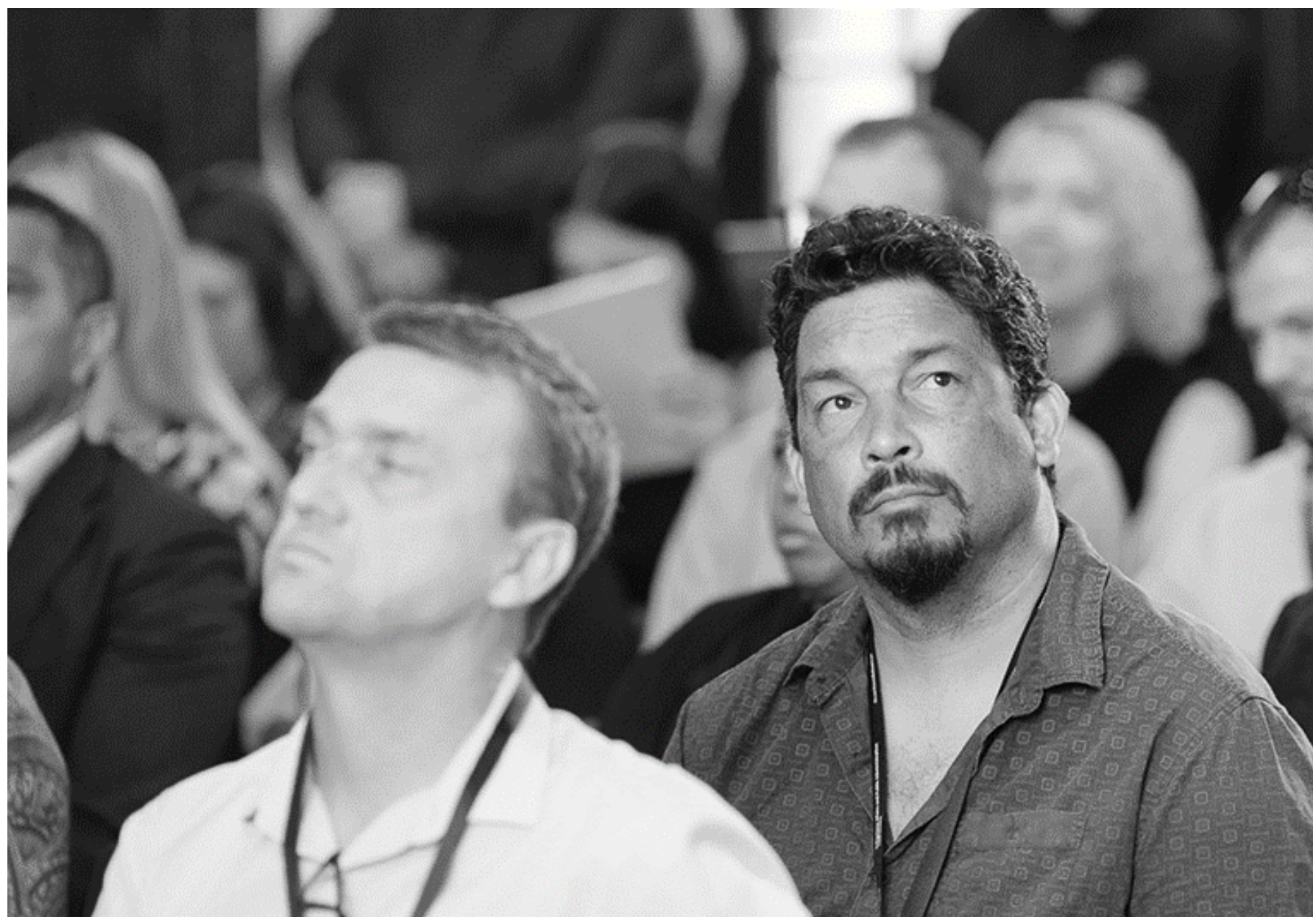


Australia \&

New Zealand

School Of

Government

ANZSOG 